\title{
ACCOUNT OF A CASE
}

\section{IN WHICH THE \\ CAESAREAN SECTION WAS PERFORMED; \\ wITH}

\author{
REMARKS ON THE PECULIAR SOURCES OF DANGER ATTENDANT \\ ON THE OPERATION. \\ BY \\ CHARLES WEST, M.D. \\ PHYSICIAN-ACCOUCHEUR TO ST. BARTHOLOMEW'S HOSPITAL, AND \\ LECTURER ON MIDWIFERY IN THE MEDICAL COLLEGE.
}

Received December 20th, 1850.-Read January 28th, 1851.

There are some subjects connected with the exercise of our profession, concerning which scarcely any one can be said to have experience, but each has to fall back upon the accumulated observation and experience of many others. This circumstance attaches a real value to the publication of isolated cases, and must serve as my apology for bringing the following history before the notice of the Fellows of the Medical and Chirurgical Society.

Elizabeth Williams was one of eight children, of whom seven reached adult age. Her father, who had been insane for some years previously, died at the age of 73 , her mother at that of 68 . Two of her brothers and one sister died of phthisis, and this sister was insane for some years before her death. Two brothers and a sister survive in good bodily health, but the sister is of weak intellect; and Elizabeth herself had, on more than one occasion, shown indications of insanity. 
As a child, E. Williams's health had been good, but it became much impaired about the age of 15 , when she began to menstruate; and ever since then she had frequently, indeed almost constantly, suffered from pain in the back, referred especially to the pelvis. About the age of 23 the pain became much severer than it had ever been before; but, in spite of this, and of the advice which she received from some medical man not to marry, she married, at the age of 25, the husband of her deceased sister. She did not become pregnant until fifteen months after marriage ; but conception was followed by a very considerable increase of pain, associated, during the latter half of her pregnancy, with a great and rapidly increasing difficulty in walking. For some weeks before her confinement she did not move further than from her bedroom on the second floor to her sitting-room on the first floor, where she generally spent the whole day lying or sitting upon her sofa. Sometimes, however, she moved about her room, and, on the day before her confinement, was occupied in putting up curtains to the windows; her disinclination to walk seeming to be due, at least, as much to her nervous temperament and wayward disposition, as to any physical incapacity for exertion.

She was in the fifth month of her pregnancy when she placed herself under the care of Mr. Wren, of Brownlowstreet, to whose kindness I am indebted for many facts in her history, as well as for the permission to lay her case before this Society. There was nothing in her appearance, either when she first came under. Mr. Wren's care or subsequently, to suggest the idea of her being deformed; the only peculiarity which she presented being that she always stooped very much forwards. During her pregnancy her bowels required the constant use of purgatives; her appetite was bad, she was much annoyed by heart-burn, had occasional faintings, and suffered much from palpitation; her pulse beating habitually 120 in the minute, (a rate of frequency which she said it had manifested for years), but varying under every source of excitement. She was nervous and excitable in the highest degree, looking forward with much 
apprehension to her labour, and especially to the pain attending it; and was urgent in extorting a promise that she should be permitted to inhale chloroform when labour came on.

It was in this unfavorable state, both of body and mind, though much benefited by Mr. Wren's treatment, that Mrs. Williams reached the end of her pregnancy, and labourpains came on at 1 a.m. on the 7 th of May, 1850; she having been married just two years, and being in the 27th year of her age.

Mr. Wren was summoned at 3 a.m., and discovering, on his first examination, the existence of extreme pelvic deformity, despatched a messenger for me ; and I arrived at a quarter to 5 a.m. I learned that the pains which the patient had had were very feeble, and returned only about every quarter of an hour. She bore them, however, very ill, tossing about the bed, crying out for chloroform, and becoming almost unmanageable on any attempt to make a vaginal examination.

She was a small, slim person; and as she lay in bed presented no sign of deformity, and her extremities were straight and well formed. Her face was pale, and her pulse frequent and feeble. On examining her spine it was found to be perfectly straight, but the sacrum was bent into an almost semicircular form, with a great convexity projecting backwards; the pubic arch was a little wider than would suffice to allow of laying one finger between the rami of the pubes; the tuberosities of the ischia did not seem to be much above an inch apart, and the rami of the pubes ran out into a sort of beak; the bones being bent at the junction of the pubis and ischium, and being at this point not more than an inch apart.

The os uteri could be reached with difficulty; it was open to about the size of half a crown; its lips were still thick, but soft.

At a quarter to 10 a.m., Dr. Ramsbotham and Dr. Murphy saw the patient with Mr. Wren and myself; her case appear. ing to us to be one in which, even irrespective of the interests 
of the child, the Cresarean section was called for. Auscultation, moreover, had ascertained the child to be living.

Pains had occurred, though feebly, since 5 a.m., and the os uteri was now found by Dr. Ramsbotham to be fully dilated. During his examination the membranes broke, and liquor amnii escaped, though not in any large quantity. The head was found to be presenting.

The circumstances which seemed to point out the Cresarean section as the only admissible proceeding, were not merely the probability of the existence of a very considerable degree of contraction of the pelvic brim, but also the extreme narrowness of the outlet, which would render the introduction of the hand to guard the embryotomy instrument impossible; while even supposing the head of the child to have been so mutilated, as to admit of its extraction, it was yet doubtful whether the body could be extracted, and the rather, since the narrowness of the outlet would quite prevent any attempt at evisceration from succeeding.

On the other hand it might be alleged, that though any attempt at extracting the child would be both dangerous, difficult, and tedious, and would most likely occupy some two or three hours, yet it could probably be effected. Although it was quite true that, should serious difficulty occur in extracting the body, it would not be possible to eviscerate the child, yet the chances were against the existence of any such difficulty as to be absolutely insurmountable; while, though injury might be inflicted on the mother, yet injuries to parts within the pelvis being so much less formidable than injuries to the uterus itself; the endeavours to deliver by the natural passages would, on the whole, be preferable, as far as the mother was concerned, to the more hazardous experiment of the Cæsarean section.

Dr. Ramsbotham's opinion inclined to the latter view; but although he thought the fotus might, by great exertion, be dragged through the pelvis after craniotomy had been effected, he nevertheless acquiesced in the view that Dr. Murphy and myself took, of the great danger necessarily attending such forcible efforts; and this, in addition to the 
possible chance of ultimate failure, induced him to agree with us, and to sanction the performance of the Crsarean section. It was determined to request Mr. Skey, who was the only surgeon in the metropolis who had ever performed the operation on the living subject, to undertake it. To this request Mr. Skey kindly acceded, after he had been made acquainted with the particulars of the case; and it was in conjunction with him that the subsequent treatment of the patient was carried out.

As no circumstance seemed to indicate the necessity for earlier interference, 4 o'clock p.m. was the hour fixed for the operation. For permission to lay before the Society the details of its performance, I have to acknowledge my obligation to the kindness of Mr. Skey.

On assembling at 4 o'clock, we found that the patient had had but very little uterine action; her bowels had been relieved by an enema, and she had taken a little beef-tea occasionally. The necessity for the performance of the Cæsarean section being explained to her, she readily consented to undergo it, but on condition that she should be previously rendered insensible to pain by the use of chloroform; and no representation of the comparatively slight suffering which the operation would occasion, or of the possible increase of danger to which the employment of chloroform might expose her, could at all shake this resolution.

On receiving the assurance that her desire, in this respect, should be complied with, she at once became contented, went quietly through all the preliminaries of the operation, and, during her subsequent illness, showed a remarkable degree of equanimity and patience, which were interrupted only when the wound was dressed, and the apprehension of pain then rendered her immediately excited, and difficult to manage.

The patient was now placed on a table, with her feet resting on two chairs, and her shoulders somewhat raised; the catheter was passed, and a small quantity of urine drawn off; the fotal heart was distinctly heard, beating in the XXXvi. 
right half of the abdomen, but the uterine souffle was not clearly perceived anywhere; facts, the inferences from which were confirmed during the operation.

An assistant being stationed on each side of the patient, to prevent the escape of the intestines, and the inhalation of chloroform having begun, Mr. Skey now marked the line of the incision with ink ; and so completely was the contour of the abdomen altered by the contraction of the pelvis, that the incision, seven inches in length, was carried two inches above the umbilicus, and down to the commencement of the pubic hair, and it was afterwards found necessary to carry it an inch higher.

Inhalation of chloroform began at 18 minutes past 5 ; at $25 \frac{1}{2}$ minutes past 5 the first incision was made, and at $31_{\frac{1}{2}}$ minutes past 5 the child was extracted, the operation having been somewhat delayed by the circumstance that the patient began to struggle after the first incision, so that it became necessary to pause, in order to give her more chloroform.

The abdominal integuments were extremely thin; no bleeding took place from them. On opening the peritoneum, about a drachm of transparent serum escaped; and on dividing it to the whole extent of the external wound, the uterus presented itself, occupying it so completely that no intestines were to be seen. The uterus was turned obliquely on its long axis, the right fallopian tube and ovary being distinctly in view, the front of the uterus looking towards the left side, and the organ corresponding in its direction very nearly to that of the left oblique diameter of the pelvis. Care was taken, however, to make the incision in the mesial line of the uterus. The walls of the outer half of the uterus bled comparatively little; but the bleeding from the vessels of the inner half was free, though not alarming. The total thickness of the uterine wall was about three quarters of an inch. The cavity of the uterus was opened at the lower part of the wound, and a director of peculiar construction, invented by Mr. Skey for the purpose, and used by him in his former operation, was then introduced, and the incision carried upon it quite up to the fundus of the womb. The 
child was now seen lying in the third position of Naegele (the second of most authors), namely, with its back to the right, and forwards. The membranes were at once torn through, and the child, a fine girl, was taken out. Its surface looked slightly livid, and for a few seconds it did not cry. It then, however, began to breathe, and in two or three minutes cried loudly, without any measures having been needed to resuscitate it. It may, perhaps, be as well to add, that the child still survives, and is in good health.

The uterus did not contract much; it diminished, indeed, in length, but the wound remained widely open, and the placenta was seen attached to the posterior part of the organ. The uterine cavity was now filled with blood, and the placenta looking as if it were entirely detached, it was removed by Mr. Skey; who found, however, that its complete separation required rather firm traction.

No sooner was the placenta removed from the uterus, than the blood welled up from it, partly from its interior, partly from its cut edges, just like water gushing from a spring; a profuse, steady, uniform stream running down upon the floor, and which seemed, for a few seconds, as though it would not cease so long as there was any blood to flow. From a pint and a half to a quart of blood was thus lost; and, during the continuance of this very profuse bleeding, the patient's pulse became very feeble, though it never altogether ceased; while, owing to the insensibility previously produced by the chloroform, it was some minutes before she could attempt to swallow. The first indication of returning consciousness was furnished by several violent attempts to vomit, during which the intestines (especially on the left side of the uterus), which had come into view immediately on the removal of the child, prolapsed, and could with difficulty be retained in the abdomen, even by closing the integuments over it.

By degrees the hæmorrhage abated; no other means having been resorted to, to excite uterine action, than moderate pressure with the hand on the abdomen. At 6 p.m., the hæmorrhage had quite ceased, though the uterus 
was not firmly contracted, nor the wound closed tight. Five sutures were now placed in the abdominal integuments, the last, one inch and a half above the lower edge of the wound; a space being left here at my request, in compliance with the suggestion of some continental surgeons, who attach importance to an aperture being left for the escape of the discharges from the uterine wound. Broad strips of plaster were next applied; and an eighteen-tailed bandage, which had been placed under the patient before the operation was begun, was now brought together over some large sheets of cotton wool, which served to protect the abdomen from pressure.

The patient was now carefully lifted into bed; and immediately on being placed there, efforts at vomiting came on, during which firm pressure was made on her abdomen, to prevent, if possible, protrusion of the intestines. As soon as they had a little subsided, sixty drops of Tincture of Opium, were given in a little brandy, but were almost immediately rejected, and she refused to take any more laudanum, saying it would make her vomit.

At this time, though her pulse was extremely feeble and her extremities were cold, yet her mind was calm and collected, nor did her intellect become at all disturbed, until within an hour or two of her death.

Two doses of morphia were given her between 7 and 10 p.m., but both were rejected soon afterwards, and the patient made frequent efforts to vomit during the first two hours after the operation. At 10 p.m., however, she expressed herself as feeling comfortable, and her pulse, though extremely feeble, did not exceed 108 beats in the minute. On examining the wound, a portion of omentum was seen to have escaped beneath the lowest suture, and having been returned with some difficulty, an additional suture was put in to close the lower edge of the wound, and the renewal of the accident was thus prevented.

In consequence of the irritability of her stomach, it was determined to endeavour to keep the patient under the influence of opium, and to supply her with nourishment mainly by means of enemata; and accordingly a drachm and a half 
of laudanum was thrown into the rectum at midnight; and was followed in about an hour by an enema of four ounces of strong beef-tea, thickened with isinglass. The laudanum in smaller doses and the beef-tea were given in enemata at intervals of about every four hours; so that during the first sixty-two hours after the operation, $3 \mathrm{v} \mathrm{m} x i v$, of the former, and $\xi x l v i i i$ of the latter, were thrown into the rectum; the beef-tea being thickened with isinglass, and occasionally mixed with brandy.

From the time of the operation to her death, the patient was watched incessantly by Mr. Cupiss, Mr. W. H. Stretton, Mr. Arthur Stretton, or Mr. Hillier, four very intelligent students at St. Bartholomew's, who not only did everything which the most unwearied care could do to save her, but also recorded, with the minutest accuracy, every change in her condition.

For the first twenty hours she dozed at intervals, though she continued in a state of great depression and vomited occasionally; but the irritability of the stomach gradually diminished; the lochial discharge appeared, and continued to flow scantily, but without any unnatural character during the remainder of the patient's life. She passed water, throughout the whole of her illness, without any difficulty, and suffered scarcely any pain; while the distressing efforts to vomit were always relieved, sometimes entirely arrested, by firm pressure upon the abdomen. Her condition during the 8th of May continued one of great depression; and though her sickness was less, yet she took nothing more than a little ice, and a spoonful of milk occasionally. Her pulse was 148 at 10 p.m. ; having been 160 at the same time on the previous day. Moreover, she bore the cutting off some of her soiled linen very well, and expressed a wish for some wine.

She passed the night of the 8th of May on the whole comfortably, dozed a good deal, and took wine-and-water frequently; but was slightly sick at 5 a.m., on the 9th; when she threw up a little clear fluid, being the first time of her vomiting for more than twenty hours.

During the day she took sago and milk readily, but refused 
wine; and continued apparently better till half past 3 p.m., when she vomited a dark brown, offensive fluid; and this vomiting recurring thrice before 10 p.m., left her evidently deteriorated, and she passed a more restless night than the preceding one had been.

At a quarter to 7 a.m., on the 10th, vomiting of green matter had returned, and the patient seemed more feeble. She had taken very little by the mouth, and the disposition to sickness and distaste for almost everything, with the inability to bear more than a teaspoonful or two of any nourishment at a time, interfered greatly with all endeavours to support her powers. She had complained sometimes of headache, especially when sickness was felt; and it became a question with Mr. Skey and myself whether any advantage likely to accrue from the continuance of the laudanum in the enemata was such as to counterbalance the possible evil of maintaining a constipated condition of the bowels, and of keeping up or aggravating the patient's sickness. The character of the matters vomited seemed, indeed, to point to a more serious and less remediable cause; but still it was determined to try the effect of omitting the laudanum.

Various stimulants and various articles of food were tried during the course of the day, but she took very little of any; champagne and ice being the two things that seemed most grateful to her. She had one or two returns of green vomiting during the day, but did not appear, at 11 p.m., to have at all retrograded since the morning.

She became very restless, however, and was sick twice after 11 p.m. ; the opium was accordingly resumed in the enemata, and early on the morning of May the 11th, small doses of the black drop were given every two hours at Dr. Murphy's suggestion. By 3 p.m., under the continuance of the opium and the enemata of beef-tea, with such small amounts of food and stimulants as she could be induced to take, she rallied surprisingly; the lochial discharge, which had almost ceased for the previous twelve hours, reappeared; and her pulse, which had ranged at about 140 to 150, though still 146, was somewhat less feeble. 
At 3 p.m., Dr. Ramsbotham, Dr. Murphy, Mr. Skey, Mr. Wren, and I, saw her together, and felt more hopeful about her than at any time for the previous twenty-four hours. There was, however, one bad symptom about her even then, which was that her temperature, which during the night had sunk very low, continued so, and that there was a cold perspiration upon her surface. Almost immediately after this visit, too, the other favorable symptoms began to disappear; her skin became quite cold, her pulse thready, and she sank into a state of collapse like that of a cholera patient, her intellect continuing clear, and considerable muscular power remaining, until within a couple of hours of her death, which took place at half-past $6 \mathrm{a.m}$, on May 12th; $108 \frac{1}{2}$ hours after the operation.

At the examination of the body $33 \frac{1}{2}$ hours after death, the abdominal cavity and the pelvis were alone examined.

Decomposition had already advanced; the body gave out a very offensive odour; there were livid spots on the surface of the abdomen, which was tympanitic.

The external wound was now six inches long; union had taken place for about two inches at its lower edge, and about the situation of the fourth suture, but elsewhere its edges were gaping.

A portion of healthy omentum, about two inches long, was found lying free at the lower edge of the wound beneath the integuments, but external to the peritoneal cavity.

There was no effusion of fluid into the abdominal cavity; the viscera were all exceedingly bloodless, but a thin layer of dirty yellow lymph connected the opposite surfaces of the pale, large intestines to each other, and also at some points united the intestines to the uterus.

A thick layer of yellow lymph lined the abdominal walls from the umbilicus downwards. On stripping it off, the peritoneum appeared thickened, and destitute of its natural polish, but scarcely, if at all, increased in vascularity. The intestines contained very little fluid, no solid fæces, some flatus. 
The bladder was empty and flattened, and appeared to have adapted itself to the altered shape and relations of the parts, being almost completely out of the pelvis. It was quite pale and healthy.

The uterus was moderately contracted, but not the slightest effort had been made to close the wound, the external edges of which were retracted, and lay at least an inch apart, while the internal edges were but just in apposition.

At the wound, the substance of the uterus looked swollen and infiltrated, the wall there measuring $1 \cdot 2$ inch in thickness, while at the fundus of the organ it was only $\cdot 7$ thick. The length of the external uterine wound was 3.65 inches; of the inner $2 \cdot 5$. The edges of the wound were covered by a thin layer of a dirty brownish matter, in all probability altered blood; beneath which they were of a pale dirty, straw colour. Elsewhere the substance of the organ was pale and bloodless, looking as white as veal; presenting no sign of inflammation, no thickening of its veins, neither coagula nor blood in their channels.

The placenta had been attached posteriorly near the fundus of the uterus, but rather to its left side. The surface to which it had been attached looked quite healthy, as did the whole interior of the uterus, and also the vagina, in neither of which was there any blood nor any sort of morbid secretion.

The pelvis was a very well-marked specimen of the deformity produced by mollities ossium.

The lumbar vertebræ had been driven down into the pelvic cavity, so that, as the body lay upon its back, a line drawn from the symphysis pubis directly backwards, touched the upper part of the fourth lumbar vertebra.

The length of such a line was $4 \cdot 2$ inches.

Transverse diameter of the brim 4 .

The rami of the pubes were projected forwards into a beak, the width of which was $\cdot 75$ of an inch, while its length, measured from the inner surface of the symphysis, was 1.2 inch; by which the antero-posterior diameter was reduced to 3 inches. 
The bodies of the fourth and fifth lumbar vertebræ were much flattened, so that from the upper part of the fourth to the upper part of the sacrum they measured only 1.5 inch.

The sacrum was so greatly curved that from about its third vertebra it ran horizontally forwards. The depth of the bone to the point where it bent forwards, was rather less than one inch and a half; while from the point of the coccyx along the horizontal part of the sacrum it was $2 \cdot 75$.

Distance between the two anterior superior spines of ilia . . 8 inches.

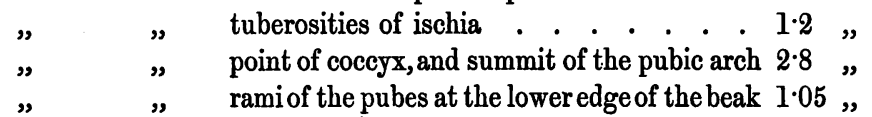

Width at the upper part of the pubic arch . . . . . . 6"

Agreeing, as I do, most cordially with the rule laid down in British Midwifery, which gives the mother's life a claim paramount to every other consideration, it cannot but be with a feeling of deep regret that I am compelled to add another to the already long list of failures of this operation. Happily, however, in this instance, the painful question which sometimes besets us after an unfortunate operation, as to

I I am acquainted with 409 authentic cases of the Cæsarean section, 341 of which are collected in Kayser's very valuable essay 'De Eventu Sectionis Cæsareæ.' In 251 of these cases the mother died; in 158 she survived. The fate of the children is mentioned in 347 instances : in 110 of which they were still-born, in 237 they were born living. There can, however, be no doubt but that these figures convey a very exaggerated impression as to the proportion of recoveries, and that the unfavorable estimate of English authors is nearer the truth. Both Kayser and Naegele regard the results given by the published cases as unfair; and the former mentions the fact, which of itself affords strong evidence on this point, that while the total maternal mortality among the cases which he had collected was 63 per cent., the mortality of cases occurring in lying-in hospitals, in which institutions failures must, of necessity, be reported as well as successes, amounted to 79 per cent. This last figure does not differ very materially from that afforded by the cases occurring in this country; 49 of which yield 7 recoveries, (or 8, if Mr. Whitehead's case, where the patient survived till the thirty-second day, and died then chiefly from the advance of disease in her lip, be classed among the number;) the rate of maternal mortality being in the former case $85 \cdot 7$, in the latter 83.6 per cent. 
whether somedifferentcourse might not have been adopted with better prospects of success, does not arise; since the extreme degree of pelvic deformity must have rendered any attempt at extracting a mutilated child almost certainly unsuccessful; while the absence during pregnancy of evidence of the contracted state of the pelvis, sufficiently accounts for no measures having been adopted for the induction of premature labour.

But though there was here no alternative left, and though if a similar case presentea itself to me to-morrow, $I$ should again advise the same course, yet it cannot be denied that the Cæsarean section is attended by perils peculiar to itself, such as beset no other operation either in surgery or obstetric practice, and which, I confess, would make me shrink from recommending its performance in every instance where the way seemed open for any other proceeding.

The dangers peculiar to this operation, and inseparable from it even when most carefully performed, may be referred to the following four heads:-

1. The danger arising from hæmorrhage, which proceeds from a source different from that whence bleeding takes place in any other operation, and which is not capable of being arrested by the same means as suppress it under ordinary circumstances.

2. That dependent on the shock inflicted on the nervous system, as well by the violent interference with the most important process that ever goes on in the organism within the same limited time, as by the injury to a part so important and so richly supplied with nerves as the uterus of a parturient woman.

3. The hazard inseparable from extensive injury to the peritoneum, when unblunted in its sympathies and unaltered in its texture, as in cases of ovarian or other tumours, for the removal of which a similar exposure of the abdominal cavity is sometimes practised.

4. That which results from the infliction of a wound on the uterus, at a time when, in the ordinary course of things, the processes which nature is prepared to carry on in it, 
consist in the desintegration and removal of its tissue; the very opposite, indeed, to those essential for the repair of injury.

To all, except the last of these sources of danger, attention has been more or less directed; but still the amount of peril to which the patient is exposed from each, has, perhaps, been scarcely sufficiently investigated.

Kayser, in his valuable essay on the Cæsarean Section, states the cause of death in 123 cases; in 77 of which the patient died of inflammation, in 30 from the shock to the nervous system, in 12 from hæmorrhage, and in 4 from some accidental occurrence not of necessity associated with the operation. In some of these cases, however, no post-mortem examination was made; in others the date of the patient's death is not stated; while in several, more than one of the above-mentioned causes had contributed to occasion the patient's death. Selecting, therefore, such of Kayser's cases as were complete in all respects, and adding to them such others as have since come to my knowledge with the requisite details, I have drawn up the accompanying table, as affording some approximation to a correct view of the causes of death after the Cæsarean section.

From this table it appears that, in 411 out of 147 cases, a notable amount of hæmorrhage occurred either during the operation or subsequent to it; and in a third of this number hæmorrhage was the sole cause of the patient's death. In seven instances the hæmorrhage arose, in great measure, from the placenta being wounded in the course of the operation; an accident which probably might be aroided in the majority of instances, by careful preliminary auscultation. In twenty instances it occurred at the time of the operation, and proceeded in part from the edges of the wound, in part, and usually in greater measure, from the seat of the placenta, and followed its detachment or spontaneous separation. In the remaining fourteen cases the more important bleeding was secondary, taking place after the completion of the operation and closure of the wound, escaping externally 
in one or two instances, but in the other cases being poured out into the abdominal cavity, and being discovered in the form of coagula of greater or less magnitude, on examination of the patient's body after death.

Against this hæmorrhage the resources of art can effect but little. The injury of the uterine substance can hardly fail to impair the contractile power of the organ, while that arrangement of the uterine sinuses which tends to prevent the occurrence of hæmorrhage after the separation of the placenta, even where the womb remains uncontracted, can be of no service in checking the bleeding from the wound.

It does not seem easy to say why profuse bleeding has occurred in some cases and not in others, and the impossibility of estimating the dangers of the operation before-hand with any near approach to correctness, is to my mind by no means the least of the difficulties that attend upon it. It may, perhaps, be thought that, in the case related above, the administration of chloroform had something to do with the very tardy contractions of the uterus; and my own experience of this agent, which I frequently employ in obstetric operations, inclines me to believe that this may have been the case, though it must not be forgotten that the uterine action was very feeble even from the commencement of labour. Serious hæmorrhage attended on four ${ }^{1}$ out of seven cases of the Cæsarean section in which anæsthetic agents were employed; but in $t^{2} o^{2}$ the action of the uterus continued vigorous, although the patient was in a state of complete unconsciousness; while Mr. Skey's patient, on whom he operated at St. Bartholomew's, was never thoroughly under the influence of the ether; and the hæmorrhage in Dr. Nimmo's recent case depended, in great measure, upon the placenta having been wounded. The risk of serious hæmorrhage is doubtless diminished by not operating till after the

1 Namely, the present case, and those of Mr. Skey, Dr. Nimmo, and Professor Hüter; numbers 109, 111, 102, and 8 in the Table of reference.

2 The cases of Mr. Campbell, No. 60, and Dr. Oldham, No. 131; besides which it was employed with advantage in Dr. Oldham's late successful case, reported in the 'Medical Times' of August 16, 1851. 
liquor amnii has escaped or been evacuated; but the danger of exciting violent peritoneal inflammation, is probably a sufficient reason against following the practice of Professor von Ritgen of Giessen, ${ }^{1}$ who advises that the uterus be drawn forwards, and surrounded with sponges dipped in cold water, till vigorous and permanent contraction has been induced; though in one or two cases which terminated successfully this proceeding has been adopted.

The shock to the nervous system is a very serious cause of the mortality of patients who undergo the Cæesarean section. In thirty-three of 147 fatal cases, the patient sank under the shock; no hæmorrhage having either attended the operation or followed it, and no morbid appearances having been discovered after death. In eleven cases more, though the more prominent symptoms during life were those of shock, yet examination after death discovered the effects of previous inflammation; and reference has already been made to nine other cases where the symptoms of shock might be, in measure, due to the loss of blood.

Two causes, both alike beyond the control of the practitioner, expose the patient to this shock: one, the sudden interruption of the labour; the other, the injury to the womb; and the feeble person, exhausted by previous disease and suffering, and therefore least able to bear up against their influence, is she whose case, in general, most urgently calls for the performance of this operation. The employment of opium in large and frequently repeated doses, as originally suggested by Dr. Stokes, in cases of peritonitis from perforation of the intestines, and of the successful adoption of which, in a case of rupture of the uterus, Dr. Mitchell has related $^{2}$ a very interesting example, would probably do something towards warding off the symptoms of collapse. The discontinuance of the opium, in the case just recorded, was probably injudicious; and the patient's brief rallying afterwards was, perhaps, due to its readministration. At the

1 Neue Zeitschrift für Geburtskunde, Bd. ix, s. 212.

2 Dublin Journal of Medical Science, Jan. 1843. 
same time, the recovery of those patients who have survived the operation, does not seem to be attributable to the adoption of any one appropriate and well-considered plan of treatment; but their history is characterised by the very slight degree in which the shock was experienced, or the rapidity with which it spontaneously passed away; so that the fortunate issue of the operation appears to have been due to the vigour of the patient, rather than to the skill of the doctor.

In fifty-six out of the 147 cases, or in 37 per cent., the symptoms during life, and the appearances discovered after death, were those of inflammation of the peritoneum, or, in some cases, of the uterus, and, in not a few instances, the morbid processes are said to have issued in gangrene. In twenty-nine cases more, the consequences of inflammation were found after death, though its symptoms were more or less masked by those dependent on previous hæmorrhage, or on the shock of the operation. It certainly can be no cause of surprise, that in eighty-five out of 147 cases, or in 57 per cent., the evidences of peritoneal inflammation should have been present; for, in addition to all those influences peculiar to child-birth, which render peritoneal inflammation more frequent then than at any other time, there is superadded the extensive injury inflicted by the operation, the long exposure of the abdominal cavity, and the subsequent escape, in many instances, of blood, or of the uterine discharges into it. Moreover, in addition to all of these causes tending to produce serious inflammation of the peritoneum, there is the absolute necessity of the occurrence of some degree of inflammation for the closure of the wound, and the repair, in as far as nature can effect it, of the grievous injury which has been inflicted by the operation. How narrow must be the limits which, in a patient who has undergone the Cæsarean section, separate the healthy action essential to repair, from the morbid action that tends to destruction!

The state of the wound has, unfortunately, engaged less attention than the interest and importance of the inquiries 
on which it bears, might well demand. Still, even from the imperfect data with which we are furnished, it seems clear that one of the first steps which nature takes towards the repair of the injury in these cases, consists almost invariably in the setting up of inflammation of the peritoneal surface of the uterus, and of the corresponding portion of the abdominal peritoneum, or, less often, of the peritoneal surface of the intestines; with the view of forming adhesions all round the wound of the uterus, and thus isolating it from the cavity of the abdomen. This being effected, adhesion takes place between the cut edges of the peritoneum; which, lymph effused upon its surface, strengthens, though this often takes place but slowly, and, for a long time, imperfectly ; as, for instance, in a case related by Professor von Ritgen, ${ }^{1}$ in which a fistulous communication between the surface of the body and the interior of the womb did not close till the sixty-fifth day. Afterwards the divided tissue of the uterus itself, in some instances, becomes united, though this last step always takes place most imperfectly, and sometimes not at all.

In many of the fatal cases it has been found that no step whatever has been taken towards repair; in more the process set up has been a perverted one, and there is no attempt at adhesion, but a dirty exudation covers the pale and bloodless peritoneum extensively, or is poured out in a fluid form into the abdominal cavity; while in others, as already mentioned, parts are found with their vitality destroyed, and this not by the excessive activity of powers which, moderated, might have conduced to repair, but by their deficiency.

And this brings me to the last cause of the high mortality which follows this operation, and a cause against which skill can avail absolutely nothing, since it is inseparable from those processes which nature sets on foot after the uterus is emptied of its contents, be the period of pregnancy, at which that takes place, what it may. In a large proportion of cases, the record of the examination after death states, that the wound of the uterus was found gaping widely, even many

1 Neue Zeitschrift für Geburtskunde, Bd. ix, Heft 2. 
days after the operation was performed. In other instances it is stated that the inner edges of the uterine wound were in contact, but the outer were far apart; and that, along the whole wounded surface, no indication was to be found of any attempt at its closure; while I know of but two instances in which the edges of the uterine wound are said to have presented a granulating surface. ${ }^{1}$

Tardy, however, though the union of the wound of the uterus is, it yet takes place eventually, if the patient survives; and the history of the subsequent pregnancies and labours of women who have undergone the Cæsarean section, proves that this union must, in some cases, have acquired a considerable degree of strength. The great majority of instances, however, in which women have survived the operation, illustrate, in spite of the incompleteness of their record, the serious difficulties in the way of a cure, and the imperfect manner in which it is almost invariably accomplished. The giving way of the uterus at the cicatrix of the operation in a subsequent pregnancy, and the escape of the ovum into the abdominal cavity, are occurrences with which all who are conversant with the history of the Crsarean section are familiar. ${ }^{2}$ Imperfect, too, as the accounts of the cicatrix are, in those cases in which death has occurred after the lapse of some months from the performance of the operation, they yet suffice to show the frail nature of this bond of union. The womb, indeed, is generally adherent to the abdominal walls, but its divided substance is almost always found ununited; the edges of the wound being closed merely by the union of the peritoneum. Even where the union has gone deeper, it has yet been effected only by means of a dense, quite unyielding, or but slightly elastic, cellular tissue; in some instances, of such low organisation as to have been found converted into a hard, almost bony, substance. How slow,

1 Whitehead, 'Medical Gazette,' Sept. 1841 ; and Kranefuss in 'Rust's Magazin,' \&c., Bd. xlv, p. 257, as quoted by Kayser, p. 87.

${ }^{2}$ Many of these cases are detailed by Professor Michaelis of Kiel, in his valuable essay on the Cæsarean Section. See his 'Abhandlungen aus dem Gebiete der Geburtshülfe;' Kiel, 1833. 
too, the processes are by which, even under favorable circumstances, this cicatrix tissue becomes assimilated to the structure of the organ in which it is developed, can hardly be better shown than by the following account by Dr. Lange, ${ }^{1}$ of the examination of the uterus of a woman who died of some chest affection nearly two years after the performance of the Cæsarean section.

"Just over the symphysis pubis there was a deep depressed cicatrix several lines in depth, and of the size of a sixpence. From the inner surface of the abdominal walls there was seen, continued from this cicatrix, a wedge-shaped prolongation, half an inch in length, as thick as the finger, of a round, but slightly flattened, shape, extending to the anterior wall of the uterus, and being closely united to it. In the interior of this band there was a cavity which communicated with that of the uterus, by an opening two lines in diameter. The interior of this conical cavity was lined by a prolongation into it of the uterine mucous membrane, and there seemed, moreover, to be a process of reproduction of uterine tissue in course of progress from the basis towards the apex of the cavity. Several bands of a callous substance, resembling that just described, ran from the sides of the larger cicatrix to the anterior wall of the uterus."

Dr. Lange remarks, concerning these appearances of which I have given an abridged description, that this sort of diverticulum proceeding from the uterus, indicates sufficiently clearly that the healing of the wound was not effected by union of its edges, but by the effusion of plastic lymph from the inflamed uterine peritoneum, and its cohesion with the inflamed abdominal peritoneum.

The surgeon who removes a limb in which gangrene has commenced, knows that, unless his incisions are made some distance above the decaying tissue, he can have no hope of the healing of the wound. The uterus, after delivery, is in

1 In a paper at p. 126, vol. iv, of the 'Vierteljahrschrift für die gesammte Heilkunde,' for 1846, which contains by far the best account of the struo. ture of the cicatrix in these cases ever yet published.

XXXIv. 
a condition, not certainly of decay, but, at least, of desintegration. Instead of there being any natural tendency to an increased afflux of blood towards it, that first step towards the repair of injury, the very discharge of its contents cuts off half the supplies of blood previously directed to it. From the weight of $\xi \times x i v$, which the organ has been ascertained to have just after delivery, it is reduced, in the course of six weeks, to a weight not exceeding an ounce and a half. This change, too, is effected, not by simple absorption, but is attended also by a general degradation of its tissue, of which the abundant presence of fat globules in the lochial discharge, and in the débris which cover the interior of the organ, is ample evidence. ${ }^{1}$ It is true, indeed, that, simultaneously with the removal of the old tissue, there goes on a formation of new; but of a tissue much more lowly organised, possessed of but small power to repair injury, and which commonly requires, for its higher development, the appropriate stimulus furnished to the uterus by pregnancy, and the sojourn of an ovum in its cavity.

The condition of the uterus in the patient whose history I have related, gave an apt illustration of the correctness of these views. The organ was generally pale and bloodless, the edges of the incision through it were swollen, infiltrated, œdematous, and discoloured by altered blood, so as to look, at first, almost as if gangrenous; and I have little doubt but that, in many of the cases in which the organ was alleged

' See Virchow's acconnt of the microscopic examination of the uterus of a woman who died fourteen days after delivery, in the 'Verhandlungen der Gesellschaft für Geburtshülfe,' in Berlin, vol. iii, p: xvii; with which the brief account by Kölliker, in the 'Zeitschrift für Wissenschaftliche Zoologie,' vol. i, p. 73, perfectly harmonises. The elaborate essay of Professor Franz Kilian, in 'Henle und Pfeuffer's Zeitschrift,' vol. ix, p. 1, furnishes a more complete account than is elsewhere to be found, both of the development of the tissue of the uterus, and of the changes which take place in it after delivery; and demonstrates the fact of the removal of the old uterine tissue, and the production, in its place, of a new and more lowly organised tissue, to which reference is incidentally made by $\mathrm{Mr}$. Rainey in his paper in the 'Philosophical Transactions' for 1850, part ii, pp. 519-20. 
to have been in a state of gangrene, ${ }^{1}$ that condition was, as in the above instance, apparent rather than real.

If, then, such and so many dangers beset this operation, if the recoveries from it be so few, and the mortality so great, while the causes of that mortality are, for the most part, beyond the power either of surgical dexterity or medical skill to obviate, and some of them inseparable from those processes which needs must follow delivery, we may, I think, feel satisfied that the general rule in British Midwifery, which prohibits the performance of the Cæsarean Section, except where delivery would otherwise be altogether impossible, rests on a far sounder foundation than that of mere prejudice, or blind obedience to the dicta of men eminent in their profession.

At the same time, these facts can yield no apology for those who, in cases calling for this operation, allow, from any cause whatever, the right moment to pass by unused. They rather leave such conduct altogether without excuse, since, by it, dangers always great are rendered insurmountable, and hopes, small at the best, are utterly destroyed.

- Many cases of an analogous condition of the uterus, in women who have undergone the Cæsarean section, might be adduced. The following may suffice from the history of a woman who died thirty days after the performance of the Crsarean section. "The wound of the uterus was slightly closed at its lower part; but at its upper end, where it had been carried quite up to the fundus uteri, it not merely gaped widely, but the absorption of its edges had gone on with such activity, that nearly the whole of the fundus uteri was consumed." - Busch, 'Geburtshülfliche Abhandlungen,' 8vo, Marburg, 1826, p. 243. He attributes this condition of the uterus to the effects of the osteomalacia, which was still advancing at the time of the patient's death; but it may, I think, with more propriety, be referred to those causes mentioned in the text as acting on the uterus after delivery. 


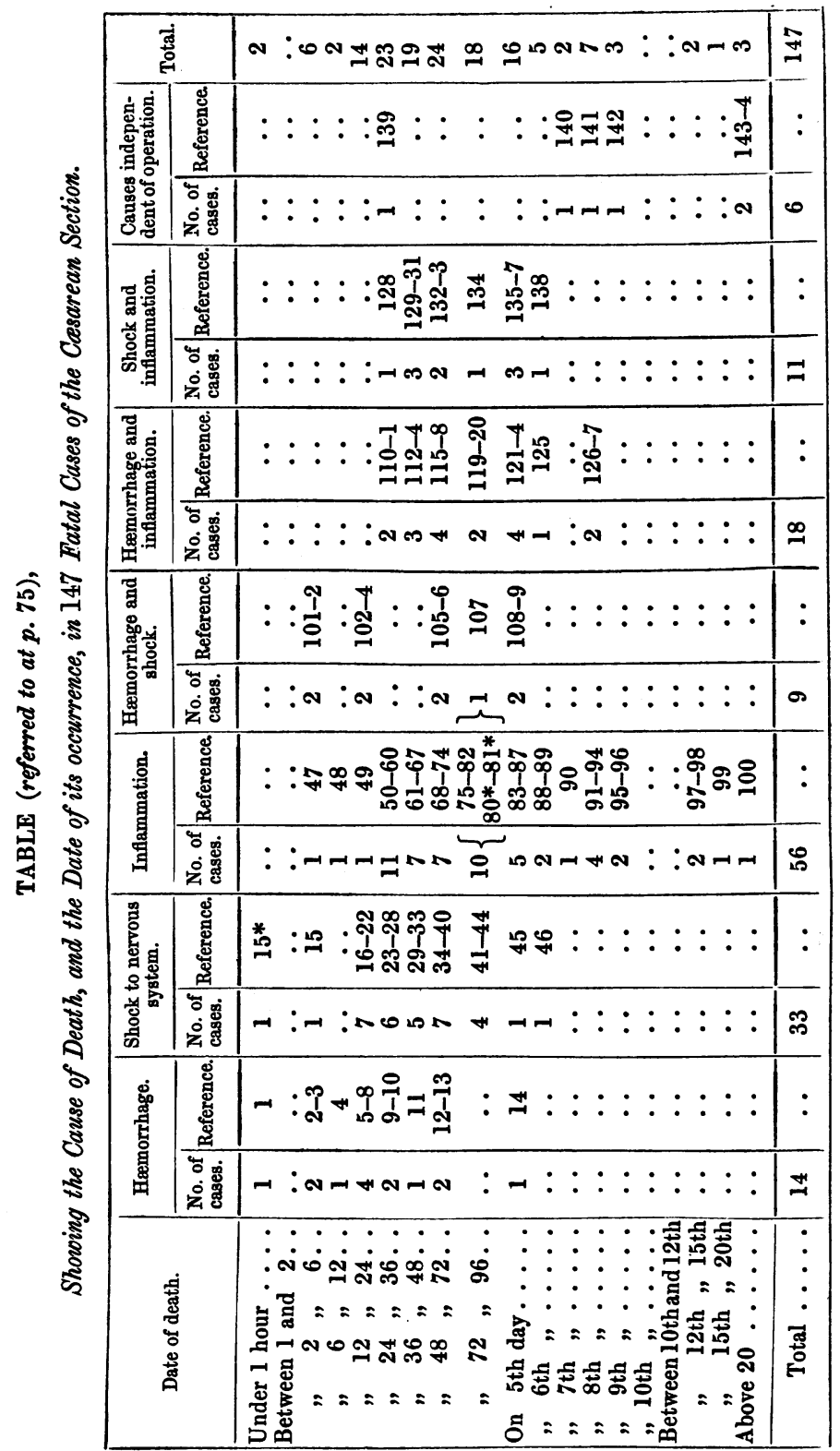




\section{References to the Cases enumerated in the foregoing Table.}

1. Bell, Medico-Chirurgical Transactions, vol. iv $\quad$. Kayser, p. 56. No. 71.

2. Thompson, Medical Records, \&c. . - p. 48. No. 37.

3. Wraith, Provincial Med. Journ., Jan. 21, 1843.

4. Engeltrum, Gemeinsame Deutsche. Zeitschr. f. Geburtsk., iv

5. Ansiaux, Clinique Chirurg., p. 63 . . . - p. 63. No. 100.

6. Baudelocque, Transact. Médicales; Septr. $1833 . \quad$ p. 86. No. 181.

7. Anonymous, at Vienna, Balfour, Northern Journ.; May 1846.

8. Hüter, Neue Zeitschr. f. Geburtsk; xxvii, p. 358.

9. Stein, Siebold's Journal ; vol. xiii . .
10. Lyon, Monthly Journ. of Med. Science, Dec. 1845.

11. Etlinger, Observationes Obstetricæ; 4to, Bonnæ, 1844.

12. Merrem, Gemeins, Deutsche Zeitschr. f. Geburtsk. ; iii, p. $341 \quad$ •

13. Johannknecht, Abhandl. d. ärztl. Gesellsch. z. Münster; 1829, p. 366 . . . . .

14. Kirchoffer, Neue Zeits. f. Geburtsk.; xix, p. 305

15. Hull, Defence of the Crsarean Operation . . 15*. Shipman, American Journal of Medical Science; July, 1849.

16. Hull, Defence of the Cæsarean Operation . $\quad$ - p. 52. No. 61.

17. Hunold, Stein, Geburtshülfl. Abhandl. _ . - _ p. 56. No. 72.

18. Henderson, Edinb. Med. Surg. Journ.; xvii, p. $105-$ p. 67. No. 113.

19. Armbruster, Stein, Lehranstalt der Geburtsk., p. $184-$ p. 73. No. 182.

20. M'Kibbin, Edinb. Med. Surg. Journ.; xxxv, p. 352 - p. 80. No. 158.

21. Thibault, Arch. Gén. de Médecine; June 1844 .

22. Montgomery, Dublin Journal; Jan. 1835* . .

23. Chalmers, Hamilton's Outlines of Midwifery; Edinb. 1806, p. 293 . . . . .

24. Cooper, Med. Observ. and Enquiries; $\nabla \quad . \quad$ - _ p. 46. No. 41.

25. Juppin, Journ. de Méd. Chirurgie, \&c.; liv, p. $65-$ p. 49. No. 49.

26. Baudelocque, Recueil Périodique; v, p. 435 - — - p. 55. No. 69.

27. Kottmann, Rheinische Jahrb. f. Med. u. Chir.; vi, pt. 2.

28. Legroux, Révue Méd.; iii, p. 353

29. Textor, Neue Zeits. f. Geburtsk.; v, p. 161 . $\quad-\quad-$ p. 88. No. 190. 30. Dohlhoff, Rust's Magazin, vol. lii ․ . . - - p. 91. No. 199. 
31. Wolff, Neue Zeitschr. f. Geburtsk.; viii, p. 354 . Kayser, p. 92. No. 203. 32. D'Outrepont, ibid. ; xiii, p. 431.

33. Etlinger, Observationes Obstetricæ ; p. 49.

34. Klein, Loder's Journal ; vol. ii _ _ . - _ p. 55. No. 68.

35. Assalini, Michaelis, Abhandlungen; p. 87, obs. 17 p. 66. No. 108.

36. Busch, ibid.; p. 94, obs. 37 . . . . - p. 73. No. 131.

37. Carus, Gem. Deuts. Zeits. f. Geburtsk.; ii, p. 406 p. 76. No. 143.

38. Gräfe, Berlin. Med. Zeitung; 1832, No. 16 . . - _ p. 82 . No. 163.

39. Moreau, Arch. Gén. de Méd.; Férr., 1838 . - p. 90. No. 197.

40. Cox, Provincial Med. Journ.; Sept. 18, 1844.

41. Deleurye, Obs. sur la Section Césarienne . . _ _ p. 48. No. 48.

42. Kluge, Siebold's Journal; viii, p. $72 \quad$. $\quad$ - p. 78. No. 149.

43. Emmert, Schmidt's Jahrb.; 1847, No. 8.

44. Grenser, Neue Zeits. f. Geburtsk.; xxv, p. 242.

45. Wiedemann, Siebold's Lucina; vol. i, pt. 3 .

46. Serres, Baudelocque, Recueil, \&c.; v, p. 428

47. Oesterlen, Michaelis, op. cit. \& p. 90, obs. 27

48. Wood, Med.-Chir.-Trans,; vol, vii

49. Kellie, Ed. Med. Surg. Journ.; vol. viii, p. 11 . - p. 64. No. 102.

50. Stein, Annalen d. Geburtsk.; pt. 3 . . . - p. 46. No. 42.

51. Wood, Memoirs of Med. Soc. of London; vol. $\nabla$. - p. 55. No. 70.

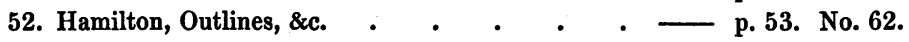

53. Osiander, Comm. Soc. Reg. Med. Gott.; 1813 . - p. 60 . No. 87.

54. Decke, Rust's Magazin; vol. xvii _ . . _ p. 71. No. 126.

55. Bongiovanni, Omodei Annali; April, 1825 . . - p. 71. No. 127.

56. Michaelis, Pfaff's Mittheilungen; p. 111 . . - p. 85. No. 170.

57. Jungmann, Oest. Med. Jahrb. ; vol. xxv - _ p. 90. No. 198.

58. Radford, Ed. Med. Surg. Journ.; vol. lv, p. 67.

59. Kömm, Oest. Med. Jahrb. ; xviii .

60. Campbell, Med. Gazette ; May, 1849.

61. Roederer, Siebold's Lucina; vol. iv, pt. 1 . - - p. 44 . No. 35.

62. Baudelocque, Lachapelle, Accouchemens; vol. iii, p. 506 . . . . . . . .

63. Bongiovanni, Omodei Annali ; vol. xxix

64. Ulsamer, Siebold's Journal ; vol. $x$. . . - p. 75. No. 141.

65. Gueury, Gaz. des Hôpitaux; ;1840, No. 79 . - p. 87. No. 185.

66. Putegnat, Monthly Retrospect; Oct. 1848.

67. Balfour, Monthly Journal; Aug. 1847.

68. Seidler, Rust's Magazin; vol. xx _ . . _ p. 72 . No. 128.

69. De Beauclair, Gemeinsame Deuts. Zeits.; i, p. 115 - p. 74. No. 134.

70. Anonymous, Kleinerț's Repertorium ; vol. iv . - p. 77. No. 148.

71. Mancini, Osservationi Mediche; 1827, No. 10 . p. 78. No. 151.

72. Wendelstädt, Siebold's Lucina; iii, p. 345 . . - - p. 83 . No. 166.

73. Flamin, Neue Zeits. f. Geburtsk. ; vi, p. $400 \quad$ - _ p. 89. No. 193.

74. Brooke, Am. Journal of Med. Science; May, 1836 p. 93 . No. 206.

75. Roederer, Siebold's Lucina; iv, pt. i . . . . - p. 44. No. 36. 
76. Kenckel, Michaelis Abhandl.; p. 76, obs. 19 . Kayser, p. 45. No. 38.

77. Stein, Geschichte d. Kaisergeb. . . . . - p. 50. No. 54.

78. Osiander, Comm. Soc. Reg. Gott.; 1813 . . - p. 61 . No. 90.

79. Berger, Siebold's Journal; vol. v, p. 142 . . - - p. 68. No. 116.

80. Cornelis, Annales d. Méd. Belge; July, $1836 \quad$ - - p. 89. No. 101.

80.* Martini, Canstatt's Jahrb. f. Geb.; 1847, p. 327.

81. Dormann, ibid.; xx, p. 324.

81.* Hüter, Neue Zeitschr. f. Geb.; xxvii, p. 366.

82. Genth, ibid.; xxvii, p. 200.

83. Ohle, Salzb. Med. Chir. Zeitung, vol. 110 . _ _ p. 59. No. 83.

84. Leydig, Gem. d. Zeitschr. f. Geburtsk.; vi, p. $328-$ p. 65. No. 105.

85. Rust, Siebold's Journal f. Geburtsk., vol. xiii _ - p. 70. No. 123.

86. Siebold, Neue Zeitschr. f. Geburtsk.; xviii, p. 45.

87. Busch, ibid.; xxviii, p. 207.

88. Bongiovanni, Omodei Annali, vol. xxix _ . - p. 70. No. 124.

89. Ward, Med. Gazette; vol, xxi . . . . - - p. 93. No. 208.

90. Neuber, Hufeland's Journal; lxxxiii, p. 52 . . - p. 81. No. 159.

91. Dubois, Lachapelle, op. cit.; iii, p. 504 . _ - p. 72. No. 129.

92. Reuter, Heidelb., Clin. Annalen; x, p. 431 . . - p. 81 . No. 160

93. Coley, Case of Cæsarean Section.

94. Busch, Neue Zeits. f. Geburtsk.; xxviii, p. 207.

95. Schützer, Michaelis, op. cit., p. 76, obs. 14 . - p. 43 . No. 84 .

96. Hoebeken, Bull. Med. Belge; Févr, 1838 . . - p. 82. No. 169.

97. Kranefuss, Rust's Magazin; xlv, p. 257 . . - p. 87. No. 187.

98. Hoebeken, Bull. Med. Belge; Jan. $1840 \quad$ - . - p. 92. No. 204.

99. Eck, Thom's Erfahrungen, \&c. . . . . . - - p. 54 . No. 65.

100. Ficker, Salzb. Med. Chir. Zeit.; $1806 \quad$. _ _ p. 59. No. 85.

101. Lovati, Gem. d. Zeitschr.; v. p. 137 . . . - - p. 79. No. 154.

102. Nimmo, Monthly Journal; Sept. 1850.

103. Kunsemüller, Neue Zeitschr., \&c.; xii, p. 375.

104. Sannemann, Lancet; July 13, 1850.

105. Ritgen, Heidelb. Clin. Annalen; i, p. 263 . - p. 70. No. 122.

106. Martin, Duo Sectioni Cæsareæ Exempla; 4to, Jenæ, 1850.

107. Barlow, London Med. Surg. Journal; iv, No. 96 . p. 77. No. 146.

108. Busch, Neue Zeitschr., \&c.; v, p. $170 \quad$. _ - p. 81 . No. 161.

109. The Author.

110. Ritgen, Gem. d. Zeitschr. f. Geburtsk.; v. p. 577 . - p. 80. No. 156.

111. Skey, Lancet; Feb. 6, 1847.

112. Schlegel, Michaelis; op. cit., p. 89, obs. 24 . - - p. 65 . No. 106.

113. Fritz, Oest. Med. Jahrb., vol. xix . . . - p. 91. No. 201.

114. Dubois, Archives Gén. de Méd.; May, $1839 \quad$ - — p. 92. No. 205.

115. Servaes, Siebold's Journal; vol. ii . . . - _ p. 60. No. 88.

116. Baudelocque, Lachapelle; op. cit., vol. iii . . - p. 62 . No. 95.

117. Heune, Siebold's Journal, vol. vii . . . . - p. 73. No. 133.

118. Busch, Gem. d. Zeitschr. f. Geburtsk.; iii, p. $292-$ p. 78. No. 152. 
119. Ferrario, ibid.; v, p. $140 \quad$. . . . . Kayser, p. 79. No. 153. 120. Haase, Neue Zeitschr., \&c., iii, p. 407 . . . _ p. 85. No. 180. 121. Weissenhorn, De Partu Cesareo . . . . . - p. 52. No. 60.

122. Coutouly, Recueil Period. de la Soc. de Méd.; xxxiv, p. 277 . $\quad . \quad$. $\quad . \quad$. . . - p. 53. No. 63.

123. Kilian, Gem. d. Zeitschr. f. Geburtsk.; vi, p. 324 . - p. 80 . No. 157. 124. Busch, Med. Zeitung, 1840, No. 1 . . . - p. 91. No. 202. 125. Michaelis, Siebold's Lucina, vol.v . . . - p. 60. No. 89. 126. Siebold, Weidmann, Compar. inter Sectionem, \&c. — p. 47. No. 47. 127. Siebold, Siebold's Journal, vol. i, p. 279 . . - p. 63. No. 101. 128. Meyer, ibid.; v, p. 105 . . . . . . - - p. 75. No. 140. 129. Mursinna, Journal f. die Chirurgie, \&c.; ii, p. 247 p. 58. No. 81. 130. Hooper, Lancet; Feb. 4, 1843.

131. Oldham, Med. Gazette; Feb. 21, 1851.

132. Stein, Praktische Abhandl. ü. d. Kaiserg. . . _ p. 47. No. 43. 133. Atkinson, On Division of the Symphysis . . - p. 47. No. 46. 134. Haas, Geschichte eines Kaiserschnittes ․ . - p. 51. No. 58. 135. Lauverjat, Neue Methode, \&c. . . . . . _ p. 49. No. 51. 136. Häsner, Siebold's Lucina; vol. vi . . . - p. 61. No. 92. 137. Béclard, Lachapelle; op. cit., iii _ . . _ _ p. 69. No. 118. 138. Dormann, Neue Zeitschr., \&c. ; xx, p. 324.

139. Dubois, Lachapelle; op. cit., iii, p. $495 \quad$. - - p. 83. No. 168. 140. D'Outrepont, Salzb. Med. Chir. Zeit.; 1822, v. iv — p. 68. No. 117. 141. Anonymous, Osiander, Entbindungsk.; vol. ii, pt. 2 p. 62. No. 96. 142. Schmidt, Siebold's Journal, viii, p. $257 \quad$ - $\quad$ - p. 75. No. 139. 143. Busch, Michaelis; op. cit., p. 95, obs. 38 • — p. 72. No. 130. 144. Stoltz, Medicinische Annalen, vol. v . . . _ p. 91. No. 200. 